\title{
Spiritualitas William Carrey: Tantangan dan Solusinya
}

\author{
Silci Arisanti \\ Kepala BAAK Sekolah Tinggi Teologi Excelsius
}

\begin{abstract}
The formation of Christian spirituality is the formation of character by the Holy Spirit through various means to be Christlike. The foundation of Christian human life is Christ. The basis of Christian spirituality is that the church has been raised with Christ. Christ became the bridge that connects man and God. In summary, the church lives with the risen Christ.
\end{abstract}

Keywords: Formation; Spirituality; Christian; William Carrey

\begin{abstract}
Abstrak
Formasi spiritualitas Kristen adalah pembentukan karakter oleh Roh Kudus melalui berbagai cara untuk serupa Kristus. Fondasi hidup manusia kristen adalah Kristus. Dasar spiritualitas Kristen adalah jemaat telah dibangkitkan bersama Kristus. Kristus menjadi jembatan yang menghubungkan manusia dan Allah. Secara ringkas, jemaat hidup bersama Kristus yang bangkit.
\end{abstract}

Kata kunci: Formasi; Spiritualitas; Kristen; William Carrey 


\section{PENDAHULUAN}

Kata spiritualitas merupakan suatu kata yang bersifat universal karena bisa digunakan oleh semua agama karena spirtitualitas itu sendiri merupakan saripati religius yang ada dibalik ajaran atau aturanaturan formal agama. Sebaliknya, dalam penghayatan spiritualitas, ajaran atau dogma atau doktrin suatu agama hanyalah menjadi pijakan semata sehingga dogma bukanlah merupakan hal terakhir, melainkan selanjutnya bagaimana seseorang dapat mengalami perjumpaan Yang Ilahi. ${ }^{1}$

Ada berbagai pengertian secara umum mengenai spiritualitas. Dilihat dari etimologinya kata spiritualitas berasal dari kata spirit, lainnya adalah spiritus yang berarti nafas (breath), keteguhan hati (courage), kekuatan (vigor), jiwa (soul), dan hidup (life.$^{2}$ Seringkali juga diartikan bahwa spiritualitas adalah hal-hal yang berkaitan dengan roh dan oleh karena itu bertentangan dengan hal-hal yang bersifat materi (kebendaan) dan korpus (badan atau tubuh). Ini adalah pandangan dikotomi ${ }^{3}$ yang mempertentangkan dua bagian. Bagianbagian yang berkaitan dengan roh seperti devosi ${ }^{4}$, hidup batin dan rohani dinilai lebih

\footnotetext{
${ }^{1}$ Areyne Christi, Diktat Kuliah: Spiritualitas I, Surabaya: STT Bethany, 2015, 1.

${ }^{2}$ Thomas H. Russel dan A. C. Bean, Webster Twentieth-Century Dictionary of The English Language (New York: Publisher Guild, Inc. 1938), 1597.
}

tinggi dari pada kegiatan kehidupan seharihari lainnya.

Setelah melihat pengertian umum tentang spiritualitas, sekarang bagaimana pengertian atau pandangan spiritualitas berdasarkan agama Kristen atau yang kemudian dikenal dengan Spiritualitas Kristen? Istilah "Spiritualitas Kristen" menunjuk kepada dua hal: sebuah pengalaman hidup dan suatu disiplin ilmu akademis. Sebagai sebuah pengalaman hidup istilah ini mengacu pada keseluruhan hidup Kristiani yang berorientasi pada pengetahuan transenden, kebebasan dan kasih dalam nilainilai dan gagasan luhur yang diterima dan digumuli dalam Yesus Kristus melalui Roh Kudus dalam gereja-Nya sebagai persekutuan orang-orang percaya.

Jadi, sebenarnya inti formasi spiritualitas Kristen adalah pembentukan karakter oleh Roh Kudus melalui berbagai cara untuk serupa Kristus. Fondasi hidup manusia kristen adalah Kristus. Dasar spiritualitas Kristen adalah jemaat telah dibangkitkan bersama Kristus. Kristus menjadi jembatan yang menghubungkan manusia dan Allah. Secara ringkas, jemaat hidup bersama Kristus yang bangkit. ${ }^{5}$

\footnotetext{
${ }^{3}$ Dikotomi adalah pembagian atas dua konsep yang saling bertentangan.

${ }^{4}$ Devosi adalah kebaktian yang tidak resmi.

${ }^{5}$ Christi, Diktat Kuliah: Spiritualitas I, 10-
} 
Namun, permasalahan atau fakta yang ada di lapangan sama sekali berbeda dengan makna spiritualitas Kristen diatas. Banyak orang yang mengaku bahwa diri mereka "kristen" tetapi tidak mengalami pembentukan karakter oleh Roh Kudus. Alasan yang paling nampak yaitu karena banyak dari mereka yang tidak memfondasikan hidup mereka dalam Kristus. Kristen bagi mereka adalah identitas dan bukanlah jati diri.

Melalui makalah yang berjudul "Spiritualitas Tokoh Bapa Gereja - William Carey" ini diharapkan bisa membantu orang kristen dalam membangun hubungannya dengan Tuhan melalui contoh seorang tokoh William Carey yang merupakan salah satu Bapa Gereja. Diharapkan pula dengan adanya makalah ini spiritualitas kristen bisa menempati kehidupan orang percaya dalam kerangka pertumbuhan dan pengembangan manusia batiniah yang sudah diselamatkan.

\section{ANALISIS DAN HASIL PENELITIAN}

\section{$\underline{\text { Biografi }}$}

William Carey lahir pada 17 Agustus $1761^{6}$ di lingkungan pedesaan di

"William Carey," Wikipedia Bahasa Indonesia, terakhir diubah 23 September 2015, diakses 26 September 2015, pk. 18.22 WIB, http://id.wikipedia.org/wiki/William_Carey.

${ }^{7}$ F. D. Wellem, Riwayat Hidup Singkat Tokoh-tokoh dalam Sejarah Gereja (Jakarta: PT. BPK Gunung Mulia, 2009), 53.

${ }^{8}$ Anne Ruck, Sejarah Gereja Asia (Jakarta: PT. BPK Gunung Mulia, 2011), 120.
Northamptonshire, Inggris. ${ }^{7}$ Orangtuanya adalah anggota Gereja Anglikan dan Carey menerima baptisan dalam gereja itu. Orangtuanya tidak hanya sekadar anggota dari Gereja Anglikan namun juga guru sekolah Anglikan. ${ }^{8}$ Carey mengalami berbagai macam kesulitan saat dia dalam proses dibesarkan oleh orangtuanya. Ayahnya seorang penenun yang mengajar di sekolah untuk menghidupi kelima orang anaknya. William Carey adalah anak sulung, dan ia gigih belajar membaca dan menulis, membaca cerita-cerita pertualangan seperti Robinson Crusoe dan Gulliver's Travels. Kesehatannya tidak pernah baik, tetapi ia berhasil magang pada seorang pengrajin sepatu. ${ }^{9}$

Pada tahun $1779^{10}$, kala itu usia Carey baru sekitar 17 tahun, kesaksian teman sekerjanya menarik hati Carey sehingga ia dibaptis ulang dan masuk Gereja Baptis. Ia meninggalkan Gereja Anglikan yang membesarkannya, dengan mengabaikan nasihat ayahnya, dan kian hari kian aktif dalam gereja itu. Pada saat itu Gereja Baptis dikenal sebagai sebuah gereja

${ }^{9}$ A. Kenneth Curtis, J. Stephen Lang, dan Randy Petersen, 100 Peristiwa Penting dalam Sejarah Kristen (Jakarta: PT. BPK Gunung Mulia, 2011), 114.

10"William Carey," Wikipedia Bahasa Indonesia, terakhir diubah 23 September 2015, diakses 26 September 2015, pk. 18.35 WIB, http://id.wikipedia.org/wiki/William_Carey. 
pembangkang. ${ }^{11}$ Ia menikah dan mulai berkhotbah di gereja. Ia berjalan kaki sejauh delapan mil setiap hari Minggu untuk berkhotbah di gereja yang miskin di sebuah kota tetangga. Ia mempelajari Perjanjian Baru dan bahasa Yunani dengan tekun, serta merangkap tiga pekerjaan sekaligus yaitu tukang sepatu, guru sekolah dan pendeta. ${ }^{12} \mathrm{Ia}$ menjadi seorang pengkhotbah dan guru sekolah pada siang hari, sedangkan malam hari ia bekerja sebagai seorang tukang sepatu. ${ }^{13}$ Meskipun Carey melakukan berbagai pekerjaan, ia menyempatkan diri untuk mempelajari sendiri bahasa Ibrani, Belanda dan Perancis selain bahasa Yunani ${ }^{14}$ padahal keadaan ekonominya tidak mengizinkan Carey mencapai taraf pendidikan yang tinggi. Carey adalah orang yang memiliki perhatian pada lingkungan, sehingga pada waktu senggang ia suka menanam bermacam-macam tumbuhan. Ia tertarik membaca buku-buku perjalanan dan terpengaruh oleh buku harian David Brainerd, yang menyerahkan diri mengabarkan Injil kepada orang Indian di Amerika. ${ }^{15}$

Kesehatannya semakin memburuk karena kesukaran keluarganya. Seorang bayi menginggal. Istrinya mengalami tekanan

\footnotetext{
${ }^{11}$ A. Kenneth Curtis, J. Stephen Lang, dan Randy Petersen, 100 Peristiwa Penting dalam Sejarah Kristen, 114.

${ }^{12}$ Ibid.

${ }^{13}$ F. D. Wellem, Tokoh-tokoh dalam Sejarah Gereja (Jakarta: PT. BPK Gunung Mulia, 2003), 167.
}

mental. Mereka sering kekurangan uang untuk makan yang layak. Di atas semua kesulitan ini, obsesi Carey membawa Injil ke luar negeri, sebagai kewajiban orang Kristen, meningkat. Pada abad ke-18 golongan Baptis yang bercorak Calvinis menafsirkan teologi predestinasi sedemikian rupa sehingga manusia tidak berperan sedikit pun dalam karya keselamatan. Menurut pendapat tersebut, andaikata Tuhan bermaksud menyelamatkan bangsa-bangsa yang jauh, Dia dapat menyelamatkan mereka tanpa memakai tenaga manusia sebagai pekabar Injil. Pada rapat-rapat para pendeta di kawasan itu, ia menguraikan secara khusus bahwa orang-orang Kristen harus menyebarkan Injil ke negeri-negeri yang jauh. Ia senantiasa ditolak. "Jika Allah hendak menyelamatkan orang-orang kafir itu, Ia akan berbuat demikian tanpa kau dan saya," jawab mereka kepadanya. Hingga akhirnya pada tahun 1972, Carey mengkritik Calvinisme yang ekstrem itu dalam buku, "An Enquery into the Obligation of Christian to Use Means for the Conversion of the Heathen" ("Sebuah Penyelidikan akan Kewajiban Orang-orang Kristen untuk Memberdayakan Segala Upaya Pertobatan Orang-orang Kafir), yang menyebabkan

\footnotetext{
${ }^{14}$ Michael Collins dan Matthew A. Price, Millenium The Story of Christianity: Menelusuri Jejak Kristianitas (Yogyakarta: Kanisius, 2006), 182.

${ }^{15}$ Anne Ruck, Sejarah Gereja Asia (Jakarta: PT. BPK Gunung Mulia, 2011), 120.
} 
panggilan bagi misi-misi luar negeri. Suatu karya yang amat baik, tetapi tidak ditanggapi dengan baik. ${ }^{16}$

Pada tahun 1792 itu juga Carey diundang berkhotbah di Sinode Gereja Baptis di kota Nottingham. Natsnya diambil dari Yesaya 54:2-3: "Lapangkanlah tempat kemahmu, dan bentangkanlah tenda tempat kediamanmu, janganlah menghematnya; panjangkanlah tali-tali kemahmu dan pancangkanlah kokoh-kokoh patokpatokmu! (3) Sebab engkau akan mengembang ke kanan dan ke kiri, keturunanmu akan memperoleh tempat bangsa-bangsa, dan akan mendiami kotakota yang sunyi." "17 Temanya adalah "Lakukanlah usaha besar demi Tuhan; harapkanlah yang besar dari tangan Tuhan" (Attemp great things for God; expect great things from God). Empat bulan kemudian sebuah lembaga pekabaran Injil yang pertama dalam kalangan reformatoris di dirikan dengan nama Baptist Missionary Society (Lembaga Pekabaran Injil Baptis) di Nottingham. Careylah yang menjadi pendorong utamanya. ${ }^{1819}$

${ }^{16}$ A. Kenneth Curtis, J. Stephen Lang, dan Randy Petersen, 100 Peristiwa Penting dalam Sejarah Kristen, 114. 17 Teks Alkitab Terjemahan Baru (Jakarta: Lembaga Alkitab Indonesia, 2007), 1021. ${ }^{18}$ Anne Ruck, Sejarah Gereja Asia (Jakarta: PT. BPK Gunung Mulia, 2011), 120.

${ }^{19}$ F. D. Wellem, Tokoh-tokoh dalam Sejarah Gereja (Jakarta: PT. BPK Gunung Mulia, 2009), 53.

\section{$\underline{\text { Perjalanan Misi di India }}$}

Seorang dokter Kristen, John Thomas, rela melayani di India dan ia membutuhkan rekan. Carey merelakan diri untuk pergi bersamanya. Untuk menindak lanjuti hal itu, Baptist Missionary Society mengirim mereka sebagai pekabar Injilnya yang pertama ke India. ${ }^{20}$ Situasinya tampak agak janggal. Carey mempunyai tiga orang anak kecil dan istrinya sedang hamil. Dapatkah ia sendiri menanggung beban tersebut? Tetapi ini adalah puncak impiannya. Carey terus maju melalui tur pengumpulan dana secara cepat, berita bahwa dr. Thomas dicari-cari para kreditor yang belum dibayar, penolakan istrinya untuk bergabung dengannya, dan terlambatnya pelayaran kapal. Penundaan itu memberi dia kesempatan pulang dang meyakinkan istrinya, Dorothy, untuk bergabung dengan dia. ${ }^{21}$ Kemudian, Carey dan keluarganya serta utusan pekabar Injil lainnya berangkat ke India dengan menumpang kapal barang Denmark. ${ }^{22}$ Pada tahun 1793 mereka mendarat di Kalkuta (sekarang Kolkata). ${ }^{23}$ Kalkuta adalah satu kota pelabuhan penting di India yang merupakan ibu kota negara bagian Benggala

${ }^{20}$ Ibid.

${ }^{21}$ A. Kenneth Curtis, J. Stephen Lang, dan Randy Petersen, 100 Peristiwa Penting dalam Sejarah Kristen, 114

Gereja, 53

${ }^{22}$ F. D. Wellem, Tokoh-tokoh dalam Sejarah

${ }^{23}$ Thomas van den End, Harta dalam Bejana (Jakarta: PT. BPK Gunung Mulia, 2009), 306. 
barat. Didirikan Inggris pada 1690, ditaklukan kepala daerah Benggala pada 1756, dan ditebut kembali oleh Clive pada 1757. Kolkata ialah ibu kota India antara 1833 sampai 1912. ${ }^{24}$ Kesulitan tetap berlanjut. Keadaan sangat memprihatinkan, kesehatan mereka sangat buruk, Thomas berutang lagi dan tak seorang pun bertobat. Anak mereka yang paling kecil meninggal, dan dua lainnya menjadi liar. ${ }^{25}$ East India Company melarang penginjilan, karenanya Carey beralih pekerjaan, yaitu menjadi pengelola pabrik nila di pedalaman India. Istri Carey tidak tahan hidup di tempat tersebut sehingga ia mengalami gangguan jiwa; dan ini berakibat berat bagi perkembangan anak-anak mereka. Namun, William Carey memakai kesempatan hidup terpencil di perkebunan untuk belajar bahasa Sanskrit dan bahasa Bengali. ${ }^{26}$ Selama lima tahun ia menerjemahkan Perjanjian Baru ke dalam bahasa Bengali dan mengunjungi 200 desa. ${ }^{27}$ Terjemahan pertama ini kurang baik, karena walaupun Carey sudah mengerti arti kata-kata bahasa Bengali, tetapi ia belum memahami penggunaan ungkap-

\footnotetext{
24“Kolkata," Wikipedia Bahasa Indonesia, terakhir diubah 06 Maret 2015, diakses 26 September 2015, pk. 20.21 WIB, http://id.wikipedia.org/wiki/Kolkata.

${ }^{25}$ A. Kenneth Curtis, J. Stephen Lang, dan Randy Petersen, 100 Peristiwa Penting dalam Sejarah Kristen, 114-115.

${ }^{26}$ Anne Ruck, Sejarah Gereja Asia (Jakarta: PT. BPK Gunung Mulia, 2011), 121.

${ }^{27}$ F. D. Wellem, Tokoh-tokoh dalam Sejarah Gereja (Jakarta: PT. BPK Gunung Mulia, 2009), 53.
}

penungkapannya, sehingga Akitab Bengali yang ditulisnya sulit dipahami. Pada tahun 1799 perkebunan tersebut bangkrut. ${ }^{28}$ Dan ditahun ini pula Joshua Marshman (17681837), seorang guru, dan William Ward (1764-1823), seorang tukang cetak dan redaktur koran, tiba di Serampore, dekat Kalkuta. ${ }^{29}$ Mereka adalah dua diantara empat orang pekabar Injil yang baru datang dari Inggris. ${ }^{30}$ Serampore termasuk wilayah penjajahan Denmark, dimana gubernurnya mendukung pekabaran Injil. Carey pinda ke Serampore bergabung dengan kedua orang tersebut. Mereka mendirikan sekolah untuk anak-anak orang Eropa. Carey mengajarkan bahasa Bengali kepada pegawai negeri berkebangsaan Inggris, tenaga East India Company. Dengan cara itu mereka dapat mencukupi kebutuhan misi. ${ }^{31}$ Bersama-sama dengan Carey mereka dikenal dengan sebutan Trio Serampore. ${ }^{32}$ Di Serampore, mereka menyaksikan pertobatan yang pertama, sebagian karena hasil usaha anak tertua Carey, Felix, yang sekarang menajdi seorang Kristen. ${ }^{33}$

\footnotetext{
${ }^{28}$ Ibid.

${ }^{29}$ Anne Ruck, Sejarah Gereja Asia, 121.

${ }^{30}$ F. D. Wellem, Tokoh-tokoh dalam Sejarah Gereja, 53.

${ }^{31}$ Anne Ruck, Sejarah Gereja Asia, 121.

${ }^{32}$ F. D. Wellem, Tokoh-tokoh dalam Sejarah Gereja, 53.

${ }^{33}$ A. Kenneth Curtis, J. Stephen Lang, dan Randy Petersen, 100 Peristiwa Penting dalam Sejarah Kristen, 115.
} 
Penerjemahan Alkitab diprioritaskan. Dalam waktu 30 tahun mereka menerjemahkan seluruh Alkitab ke dalam 6 bahasa, ditambah bagian-bagian tertentu dari Alkitab diterjemahkan ke dalam 26 bahasa. Terjemahan-terjemahan tersebut bersifat sementara dan belum sempurna. Perjanjian Baru terjemahan Carey perlu diperbaiki sampai delapan kali. Namun, pekerjaan ketiga pekabar Injil di Serampore (terkenal seabgai "Trio Serampore") merupakan langkah awal yang sangat bermakna dalam usaha perkembangan kekristenan di India. ${ }^{34}$ Kemudian sebuah gereja terbentuk dan terjemahan Perjanjian Baru dalam bahasa Bengali pun telah diselesaikan. ${ }^{35}$ Carey menganggap penelitian agama dan kebudayaan India sebagai tugas misi yang tidak boleh diabaikan. Ia menyusun buku tata bahasa Sanskrit. Pakar kesusastraan India menilai Carey sebagai pendiri sastra prosa dalam bahasa Bengali sehari-hari, dibanding dengan puisi yang dikarang sebelumnya dalam bahasa tinggi, yang tidak dapat dimengerti oleh orang biasa. Carey juga menerjemahkan Ramayana ke dalam bahasa Inggris. ${ }^{36}$

Pelayanan Baptis berpusat di Serampore, dimana Ward ditetapkan seabgai

\footnotetext{
${ }^{34}$ Anne Ruck, Sejarah Gereja Asia (Jakarta: PT. BPK Gunung Mulia, 2011), 121

${ }^{35}$ A. Kenneth Curtis, J. Stephen Lang, dan Randy Petersen, 100 Peristiwa Penting dalam Sejarah Kristen, 115.
}

pendeta jemaat. Orang India pertama dibaptis pada tahun 1800, Carey ingin mengabarkan Injil seluas mungkin dan secepat mungkin. Karenanya ia berjalan mengunjungi berbagai pedesaan, mendirikan pos-pos pekabaran Injil di tepi Sungai Gangga, di Orissa dan sampai ke Burma. Tujuan Carey adalah secepat mungkin mendirikan gereja asli India yang mandiri. Tujuan itu sesuai dengan hukum Gereja Baptis yang menekankan kemandirian setiap jemaat. Maka dari permulannya jemaat di Serampore berdiri sendiri, meskipun berhubungan erat dengan denominasi Baptis di Inggris. ${ }^{37}$ Carey berpendapat bahwa lembaga pekabaran Injil harus segera mendidik orang pribumi untuk menjadi pemberita-pemberita Injil bagi bangsanya sendiri. Sekolah tersebut diberi nama Fort William College. Carey mengajar bahasa Sansekerta, Bengali dan Marathi. Ia mengajar di sini selama 30 tahun. Sementara itu Carey terus menerjemahkan Alkitab atau bagian-bagian Alkitab ke dalam bahasa Bengali dan bahasa-bahasa lainnya. Terjemahan Alkitab lengkap diterbitkan pada tahun 1809. Di samping itu, Carey pun menyusun tata bahasa dan kamus bahasa Sansekerta, Marathi, Punyab dan Telugu. ${ }^{38}$ Kegiatan-kegiatan Carey di India didasarkan

\footnotetext{
${ }^{36}$ Anne Ruck, Sejarah Gereja Asia, 122.

${ }^{37}$ Ibid.

${ }^{38}$ F. D. Wellem, Tokoh-tokoh dalam Sejarah Gereja (Jakarta: PT. BPK Gunung Mulia, 2009), 54.
} 
pada pandangan-pandangannya. Berikut beberapa prinsip kerja Carey yang patut dicatat: $^{39}$ (1) Menganggap penyebaran Alkitab ke dalam sebanyak mungkin bahasa adalah salah satu azaz pokok pengabaran Injil; (2) Secepat mungkin harus didirikan suatu gereja di daerah pengabaran Injil; (3) Secepat mungkin harus dididik pendetapendeta pribumi; (4) Alam pemikiran sukusuku penerima Injil harus dipelajari sedalam mungkin.

\section{Tantangan Hidup William Carrey}

Banyak sekali tantangan yang dihadapi oleh William Carey semasa hidupnya selama ia berusaha untuk menyebarkan Injil di India, berikut adalah rangkumannya:

Pertama, Carey mengalami berbagai macam kesulitan saat dia dalam proses dibesarkan oleh orangtuanya. Ayahnya seorang penenun yang mengajar di sekolah untuk menghidupi kelima orang anaknya.

Kedua, Ia berjalan kaki sejauh delapan mil setiap hari Minggu untuk berkhotbah di gereja yang miskin di sebuah kota tetangga.

Ketiga, Ia menjadi seorang pengkhotbah dan guru sekolah pada siang hari, sedangkan malam hari ia bekerja sebagai seorang tukang sepatu.

Keempat, Keadaan ekonominya tidak mengizinkan Carey mencapai taraf pendidikan yang tinggi.

Kelima, Kesehatannya semakin memburuk karena kesukaran keluarganya. Seorang bayi menginggal. Istrinya mengalami tekanan mental. Mereka sering kekurangan uang untuk makan yang layak.

Keenam, Pada rapat-rapat para pendeta di kawasan itu, ia menguraikan secara khusus bahwa orang-orang Kristen harus menyebarkan Injil ke negeri-negeri yang jauh. Ia senantiasa ditolak.

Ketujuh, East India Company melarang penginjilan, karenanya Carey beralih pekerjaan, yaitu menjadi pengelola pabrik nila di pedalaman India. Istri Carey tidak tahan hidup di tempat tersebut sehingga ia mengalami gangguan jiwa; dan ini berakibat berat bagi perkembangan anakanak mereka.

Kedelapan, Carey ingin mengabarkan Injil seluas mungkin dan secepat mungkin. Karenanya ia berjalan mengunjungi berbagai pedesaan, mendirikan pos-pos pekabaran Injil di tepi Sungai Gangga, di Orissa dan sampai ke Burma. Tujuan Carey adalah

${ }^{39}$ Ichwei G. Indra, Jejak Juang Saksi Injil (Semarang: Pelayanan Mandiri “Mikhael”, 2010), 198. 
secepat mungkin mendirikan gereja asli India yang mandiri.

\section{$\underline{\text { Sikap Spiritualitas William Carrey }}$}

Dalam biografi William Carey memang hubungan Spiritualitas Carey tidak nampak dengan jelas. Berikut hubungan spiritualitas yang dilakukan oleh Carey yang dapat dirangkum oleh penulis:

\section{Pertama, Meskipun Carey} mengalami berbagai macam kesulitan saat dia dalam proses dibesarkan oleh orangtuanya namun ia memilih untuk gigih belajar membaca dan menulis, membaca cerita-cerita pertualangan seperti Robinson Crusoe. Ini menunjukkan bahwa Carey adalah orang yang sabar dan memiliki penguasan diri yang baik, sehingga ia tidak memberontak kepada orangtuanya.

Kedua, Ia berjalan kaki sejauh delapan mil setiap hari Minggu untuk berkhotbah di gereja yang miskin di sebuah kota tetangga. Hal ini menunjukkan bahwa Carey sangat mencintai Tuhannya dan juga mengasihi sesamanya. Ia tidak memikirkan diri sendiri dan ia memiliki kesetiaan dalam melayani Tuhan.

Ketiga, Walaupun Ia menjadi seorang pengkhotbah untuk membangun hubungan spiritualitasnya dan hubungan spiritualitas jemaat pada waktu itu kepada Tuhan, ia tidak lupa untuk menafkahi keluarganya. Ia menjadi guru sekolah pada siang hari, sedangkan malam hari ia bekerja sebagai seorang tukang sepatu. Sungguh ia adalah orang yang memiliki kebaikan dan tanggung jawab.

Keempat, Keadaan ekonominya tidak mengizinkan Carey mencapai taraf pendidikan yang tinggi. Namun ia memiliki kesabaran dan menerima kenyataan itu. Ia selalu berusaha dan menyempatkan diri untuk mempelajari sendiri segala sesuatu yang diingininya

Kelima, Kesehatannya semakin memburuk karena kesukaran keluarganya. Seorang bayi menginggal. Istrinya mengalami tekanan mental. Mereka sering kekurangan uang untuk makan yang layak. Namun, yang patut diacungi jempol adalah di atas semua kesulitan ini, obsesi Carey membawa Injil ke luar negeri, sebagai kewajiban orang Kristen, meningkat.

Keenam, Pada rapat-rapat para pendeta di kawasan itu, ia menguraikan secara khusus bahwa orang-orang Kristen harus menyebarkan Injil ke negeri-negeri yang jauh. Ia senantiasa ditolak. Ia memiliki kasih untuk menyelamatkan orang-orang di luar sana. Meskipun ia sering di tolak tapi carey bukan orang yang mudah menyerah.

Ketujuh, East India Company melarang penginjilan, karenanya Carey beralih pekerjaan, yaitu menjadi pengelola pabrik nila di pedalaman India. Istri Carey 
tidak tahan hidup di tempat tersebut sehingga ia mengalami gangguan jiwa; dan ini berakibat berat bagi perkembangan anakanak mereka. Namun, mungkin hikmat Tuhan turun atasnya, Carey memakai kesempatan hidup terpencil di perkebunan untuk belajar bahasa Sanskrit dan bahasa Bengali yang nantinya akan menunjang pelayanan pekabaran Injilnya.

Kesembilan, Carey ingin mengabarkan Injil seluas mungkin dan secepat mungkin. Karenanya ia berjalan mengunjungi berbagai pedesaan, mendirikan pos-pos pekabaran Injil di tepi Sungai Gangga, di Orissa dan sampai ke Burma. Tujuan Carey adalah secepat mungkin mendirikan gereja asli India yang mandiri. Ini menunjukkan bahwa Carey memiliki kesukacitaan sendiri dalam dirinya untuk menyebarkan Injil. Sesuatu yang sangat berguna untuk menciptakan hubungan spiritalitas tidak hanya untuk dirinya tetapi juga untuk orang lain.

\section{$\underline{\text { Karya William Carrey }}$}

Carey berhasil mendirikan berbagai gereja dan sekolah di India, menerjemahkan Alkitab ke dalam berbagai bahasa, mebuka pusat kesehatan, mendirikan seminari, dan

${ }^{40}$ Michael Collins dan Matthew A. Price, Millenium The Story of Christianity: Menelusuri Jejak Kristianitas (Yogyakarta: Kanisius, 2006), 183.

41"William Carey," Wikipedia Bahasa Indonesia, terakhir diubah 23 September 2015, menyokong reformasi sosial dengan sukses (termasuk menghentikan perlakuan kasar terhadap kaum wanita, pembunuhan anakanak, pengguguran bayi, dan sati, yaitu upacara pembakaran para janda yang sudah menjadi tradisi di sana). ${ }^{40}$

Carey menjadi sumber inspirasi bagi banyak orang untuk mengikuti jejaknya dalam bidang misionaris, termasuk ahli bahasa berbakat Henry Martyn. Sebelum meninggal dunia pada 9 Juni $1834^{41}$, Carrey telah menyelesaikan penerjemahan Alkitab ke dalam bahasa Urdu, yang tetap menjadi dasar terjemahan modern, dan menerjemahkan Alkitab ke dalam bahasa Arab dan Persia. ${ }^{42}$

Keahlian Carey di bidang praktis juga dipakai demi pembangunan negeri India. Ia mendirikan Horticultural Society (Persekutuan Ilmu Perkebunan) dengan tujuan meningkatkan metode-metode pertanian, termasuk mengimpor pohonpohon buah-buahan dari Inggris. Ia mengadakan percobaan dengan tanaman kopi, tembakau, gula tebu dan tanaman yang menghasilkan biji-bijian.

Carey adalah tokoh pekabaran Injil modern dan dikenal dalam sejarah gereja

diakses 26 September 2015, pk. 21.50 WIB, http://id.wikipedia.org/wiki/William_Carey.

${ }^{42}$ Michael Collins dan Matthew A. Price, Millenium The Story of Christianity: Menelusuri Jejak Kristianitas, 183. 
sebagai "Bapak Gerakan Misi Modern". ${ }^{43}$ Carey juga dikenal sebagai tokoh oikumenis. Dialah yang mencetuskan ide agar setiap 10 tahun diadakan konferensi bersama dari seluruh lembaga pekabaran Injil dan pekabar Injil di Tanjung Pengharapan. Ide ini tidak terwujud pada masa hidupnya sendiri, tetapi baru terjadi pada tahun 1910 di Edinburg. Pengertian kata "oikumene" dalam pengertian modern barasal dari William Carey. ${ }^{44}$

\section{KESIMPULAN}

"Spiritualitas Kristen" menunjuk kepada dua hal: sebuah pengalaman hidup dan suatu disiplin ilmu akademis. Inti formasi spiritualitas Kristen adalah pembentukan karakter oleh Roh Kudus melalui berbagai cara untuk serupa Kristus. Fondasi hidup manusia kristen adalah Kristus. Dasar spiritualitas Kristen adalah jemaat telah dibangkitkan bersama Kristus. Kristus menjadi jembatan yang menghubungkan manusia dan Allah. Secara ringkas, jemaat hidup bersama Kristus yang bangkit.

William Carey lahir pada 17 Agustus 1761 di lingkungan pedesaan di Northamptonshire, Inggris. Pada tahun 1779, kala itu usia Carey baru sekitar 17 tahun,

\footnotetext{
${ }^{43}$ H. Berkhof dan H. Enklaar, Sejarah Gereja (Jakarta: PT. BPK Gunung Mulia, 1993), 352.
}

kesaksian teman sekerjanya menarik hati Carey sehingga ia dibaptis ulang dan masuk Gereja Baptis. Ia meninggalkan Gereja Anglikan yang membesarkannya, dengan mengabaikan nasihat ayahnya, dan kian hari kian aktif dalam gereja itu. Pada saat itu Gereja Baptis dikenal sebagai sebuah gereja pembangkang. Ia menikah dan mulai berkhotbah di gereja. Ia mempelajari Perjanjian Baru dan bahasa Yunani dengan tekun, serta merangkap tiga pekerjaan sekaligus yaitu tukang sepatu, guru sekolah dan pendeta. Ia menjadi seorang pengkhotbah dan guru sekolah pada siang hari, sedangkan malam hari ia bekerja sebagai seorang tukang sepatu. Meskipun Carey melakukan berbagai pekerjaan, ia menyempatkan diri untuk mempelajari sendiri bahasa Ibrani, Belanda dan Perancis selain bahasa Yunani padahal keadaan ekonominya tidak mengizinkan Carey mencapai taraf pendidikan yang tinggi. Baptist Missionary Society mengirim Carey sebagai pekabar Injilnya yang pertama ke India. Kegiatan-kegiatan Carey di India didasarkan pada pandangan-pandangannya. Berikut beberapa prinsip kerja Carey yang patut dicatat: (1) Menganggap penyebaran Alkitab ke dalam sebanyak mungkin bahasa adalah salah satu azaz pokok pengabaran

\footnotetext{
${ }^{44}$ F. D. Wellem, Tokoh-tokoh dalam Sejarah Gereja (Jakarta: PT. BPK Gunung Mulia, 2009), 54.
} 
Injil; (2) Secepat mungkin harus didirikan suatu gereja di daerah pengabaran Injil; (3) Secepat mungkin harus dididik pendetapendeta pribumi; (4) Alam pemikiran sukusuku penerima Injil harus dipelajari sedalam mungkin. Perjelanan misinya di India diwarnai dengan berbagai macam tantangan, namun tantangan-tantangan tersebut dapat diatasi dengan adanya hubungan spiritualitas yang baik.

William Carey adalah tokoh yang memiliki spiritualitas yang sangat menarik. Alangkah baiknya bila kita bisa belajar melalui kehidupan William Carey untuk memacu pertumbuhan spiritualitas kita. Dengan begitu, kita bisa memiliki hubungan spiritualitas yang baik dengan Tuhan dan sesama. Amin.

\section{DAFTAR PUSTAKA}

Berkhof, H. dan H. Enklaar. Sejarah Gereja. Jakarta: PT. BPK Gunung Mulia, 1993. Christi, Areyne. Diktat Kuliah: Spiritualitas I Surabaya: STT Bethany, 2015.

Collins, Michael dan Matthew A. Price. Millenium The Story of Christianity: Menelusuri Jejak Kristianitas Yogyakarta: Kanisius, 2006.

Curtis, A. Kenneth, J. Stephen Lang dan Randy Petersen 100 Peristiwa Penting dalam Sejarah Kristen Jakarta: PT. BPK Gunung Mulia, 2011.

Indra, Ichwei G. Jejak Juang Saksi Injil Semarang: Pelayanan Mandiri "Mikhael", 2010.

Ruck, Anne. Sejarah Gereja Asia. Jakarta: PT. BPK Gunung Mulia, 2011.

Russel, Thomas H. dan A. C. Bean Webster Twentieth-Century Dictionary of The
English Language New York: Publisher Guild Inc., 1938. van den End, Thomas. Harta dalam Bejana. Jakarta: PT. BPK Gunung Mulia, 2009. Wellem, F. D. Riwayat Hidup Singkat Tokohtokoh dalam Sejarah Gereja Jakarta: PT. BPK Gunung Mulia, 2009. 